\title{
on freedom beyond the liberal paradigm: reading Ratna Kapur's Gender, Alterity and Human Rights
}

Feminist Review Issue 122, 177-180 (c) 2019 The Author(s) Article reuse guidelines: sagepub.com/journals-permissions DOI: $10.1177 / 0141778919845642$ www.feministreview.com

(SAGE

\author{
Vanja Hamzić
}

Here comes, at long last, a book on human rights that clears the way for going forward outside the selfcentred, self-referential and self-sufficient circle of human rights scholarship-an academic genre that, even at its most critical, always already re-reifies the liberal paradigm centred on the rights bearer. Ratna Kapur's Gender, Alterity and Human Rights: Freedom in a Fishbowl (2018) is a brave, deeply intimate portrait of no longer an imagined universal rights bearer or rights collector, whose 'good life' can be realised once it has found as many 'individual and inalienable' rights along the way as possible, but that of the freedom seeker, inquisitive about the world's interior as much as its exterior. The book is a daring piece of scholarship because-after many critical projects of pluralising, particularising and intersecting the imagined rights bearer, so as to make it more akin to the diverse worlds in which it intervened-Ratna's analysis finally allows this exemplary subject position to exit the liberal paradigm altogether, and thus enter the ostensible terra incognita of what she calls the 'non-liberal' space (ibid., p. 4). And, it is in this space, beyond liberal reason and point of reference, that the bearer will only truly become a seeker, whose road to selfhood is no longer bound by an episteme of the self so firmly anchored in Western liberalism's own historical and philosophical trajectories.

How, then, is this remarkable move achieved? What allows Ratna to not only call, as others have, for a paradigm shift in human rights scholarship, but to truly instigate one herself with this very book? First, the labour of this study is two-fold. About half the book is dedicated to retracing and reflecting on the

This is one of three Open Space contributions from the book launch of Ratna Kapur's Gender, Alterity and Human Rights (2018) held at SOAS University of London on Thursday, 25 0ctober 2018. Hosted by the Centre for Gender Studies, Ratna was invited to speak, and her presentation was followed by two reader responses from Brenda Cossman (Director of the Mark $\mathrm{S}$. Bonham Centre for Sexual Diversity Studies) and Vanja Hamzić (Senior Lecturer in the School of Law, SOAS). 
ways to freedom proposed by such radical thinkers as Michel Foucault and Eve Sedgwick-the former with his attention to political spirituality and the latter with her inquiry into Mahayana Buddhism as a praxis of meaningful freedom-as well as to Ratna's critical examination of such commonplace human rights debates as those on Muslim women's veiling practices and liberal and non-liberal queer and feminist positionalities. Unsurprisingly, human rights' firm liberal grounding is revealed at every turn, leading Ratna to these rhetorical questions:

Do we continue to cling to our critical relationship with the human rights movement and the liberal concepts that have, with naive idealism and revolutionary fervour, held out hope for a different and better future? Or do we resign ourselves to embracing the myth of human rights as a minimalist endeavour or available firefighting technique that may alleviate some forms of human suffering, and do 'nothing more', despite knowing that they are always actively pushing, protecting and reinforcing other agendas? (ibid., p. 19)

For Ratna, this choice between the maximal and the minimal doses of liberal futurity is patently false, because, whatever one's preference, it is exercised in and reinforces the conceptual space she terms the liberal imaginary. The other half of the book is, thus, dedicated to charting the possible ways beyond and outside the liberal paradigm. Ratna describes this move as 'a turn to the intimate as alternative nonliberal registers where freedom rests in self-inquiry and the transformation of the self' (ibid., p. 20). And, indeed, chapter after chapter, we are led through discursive practices of being in the world and with oneself that are anchored in, or borrow from, such philosophies of the self as Persian Sufism and the Hindu tradition of Advaita (non-dualism).

Here, the freedom seeker is personified and analysed in examples as rich and diverse as Lalla, a fourteenth-century female Kashmiri mystic and poet; Akka, an eighteenth-century female sage and metaphysician from Tamil Nadu; the contemporary Iranian-born visual artist Shirin Neshat, and especially her 2012 installation Overruled; the ritual dances of the gender-variant hijra community; and the practice of Santhara, or fasting, as a path to freedom for the Jain community. In these explorations, gender, sexuality and the perceived spiritual and bodily alterity to the concepts of the liberal self all serve as a heuristic towards one's understanding and embodying the call of the freedom seeker. The lifeworlds of Ratna's exemplary seekers find themselves on the outside of the liberal paradigm-even when temporally if not geographically close to its centre. They are unseen in that they do not embody, or identify with, the rights bearer that is at the centre of the global subjectivity-making liberal project.

And yet, as we know, the communities and subject positions such as hijre are no longer immune to the rights bearer's appeal. Ratna's book is a timely and monumental effort precisely because so many centuries-old exploratory spaces of non-dual life in people's experience of gender, spirituality and what Marilyn Strathern (1988) calls 'dividuality' have been gradually immersed into the liberal paradigm-the liberal imaginary-where the 'freedom' that awaits is contingent at best. So, what's to be done?

Gender, Alterity and Human Rights is, primarily, a call to an 'epistemic overhaul' (Kapur, 2018, p. 229). It is an exercise in knowing things and people differently, once the liberal episteme is gradually-and in some instances painfully-removed. The book performs this labour diligently and attends to many a space and subject position one finds once the social and the political, as exploratory sites, are stripped of their human rights veneer. It is also a guide to an array of non-dualist and 'dividualist' concepts of 
personhood that need not be understood as strictly 'cultural', i.e. unexportable and inexplorable for those who 'do not belong' to a particular social, linguistic or religious milieu. Quite the contrary, Ratna's book is full of opportunities for future cross-pollinations and productive contaminations.

But, in a work that is decidedly not only a critique but also a bridge from the liberal paradigm to the worlds beyond it, certain liberal dichotomies remain, such as that between 'liberal' and 'illiberal', or the rights bearer and its many 'others'. In a transitory work, in the attempt to clear the way towards extraliberal epistemes, such remnants might be necessary. They might not be so in the future.

Whilst concerned primarily with epistemic problems, this book also gestures towards an ontological turn. Thus, in her elucidation of a non-dualist perspective, Ratna writes that ' $\mathrm{t}$ ] he subject is emancipated from the state of ignorance/unfreedom when the error is understood through discernment that is directed at what one is, rather than what one knows' (ibid., p. 221). In this and many other examples, ontological difference is posited as a prerequisite for knowing differently-for knowing otherwise. I feel that this might be one of the potential future directions of Ratna's project, because it requires rethinking the locus not only of one's knowledge but also of the relationship between the epistemic and the ontological that remains, for the most part, imagined as dichotomous.

Finally, Ratna's book is remarkable also because it does not spell out the oft-announced 'end' of human rights, nor does it do away with rights as an ideality. Rather, it divests from the liberal human rights project and the liberal paradigm it continues to prop up. This leaves a possibility of human rights' 'second coming', as it were, in a future environment free from the liberal imaginary.

With these considerations in mind, the present reader is left with three broad queries, which are as much about this extraordinary book as the future directions of Ratna's research, now that certain stumbling blocks of the liberal episteme have been dealt with and cleared.

First, if we are to fully perform the epistemic overhaul promised by this book, where do we go next? What future stages would Ratna envision in her commitment to work outside the liberal paradigm as a critical legal feminist scholar?

Second, how is the ontological related to Ratna's labour in the epistemological field? What ways of being in the world would she see helpful in overcoming not only the Western ontological tradition in the dominant conceptualisations of human rights but the putative dichotomy this same tradition maintains between ontology and epistemology as key exploratory disciplines of the freedom seeker?

And third, should there be a place for human rights as an ideality outside the liberal paradigm? If so, what work should such an ideality perform instead of that assigned to it within the liberal imaginary?

But, whatever queries or future directions Gender, Alterity and Human Rights might elicit, this is a book that dares not only to imagine freedom outside the liberal paradigm but also to actively pursue it in a way that is certain to inspire an entire new generation of critical scholarship. How fortunate we are to have finally reached the stage of a new beginning! 


\section{author biography}

Vanja Hamzić is a Senior Lecturer in Legal History and Legal Anthropology at SOAS University of London. His work to date has particularly sought to shed new light on how gender-variant individuals and communities have braved the turbulent tides of colonialism, slavery and other forms of legally sanctioned oppression and how, in turn, they have developed multiple formations of insurrectionary knowledge. He is co-author, with Ziba Mir-Hosseini, of Control and Sexuality: The Revival of Zina Laws in Muslim Contexts (London: Women Living Under Muslim Laws, 2010) and author of Sexual and Gender Diversity in the Muslim World: History, Law and Vernacular Knowledge (London and New York: I.B. Tauris, 2016).

\section{references}

Kapur, R., 2018. Gender, Alterity and Human Rights: Freedom in a Fishbowl. Cheltenham and Northampton: Edward Elgar Publishing. Strathern, M., 1988. The Gender of the Gift: Problems with Women and Problems with Society in Melanesia. Berkeley: University of California Press. 